\section{Critical thinking across the ELT curriculum: A mixed methods approach to analyzing L2 teachers' attitudes towards critical thinking instruction}

Ketabi, Saeed

University of Isfahan, Isfahan, Iran (ketabi@fgn.ui.ac.ir)

Zabihi, Reza $\square$

University of Isfahan, Isfahan, Iran (zabihi@hotmail.com)

Ghadiri, Momene

University of Isfahan, Isfahan, Iran (momene.ghadiri@gmail.com)

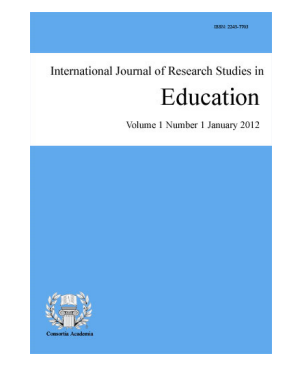

ISSN: 2243-7703 Online ISSN: 2243-7711

OPEN ACCESS

\title{
Abstract
}

The underlying assumption of recent ideas of applied ELT, life syllabus and educational language teaching is that ELT professionals should center their attention on the enhancement of learners' life skills, say, critical thinking prior to language-related skills. Despite the high premium placed on enhancing the critical thinking abilities in educational policies, and granted that English language classes have unique potentials for promoting learners' life skills such as critical thinking, it seems that ELT teachers are lacking in a true understanding of what critical thinking really means and whether or not it should be incorporated into the ELT curriculum. In the present study, EFL teachers in Iran were surveyed and interviewed regarding such a necessity. The first phase involved the collection of quantitative data via the administration of a short scale comprising Likert-style questions to Iranian EFL teachers $(N=$ 106). Analysis of the questionnaire results revealed that EFL teachers tended to express strong support for the incorporation of critical thinking into the ELT curriculum. Follow-up face-to-face interviews were carried out with a subsample $(N=5)$ selected from Phase 1 participants. The interview results added more plausibility to the survey results. The theoretical and practical implications of this study are discussed.

Keywords: applied ELT; life syllabus; critical thinking; ELT curriculum; questionnaire; interview; EFL teachers 


\section{Critical thinking across the ELT curriculum: A mixed methods approach to analyzing L2 teachers' attitudes towards critical thinking instruction}

\section{Introduction}

The expert qualification of teachers has thus been recognized to be of prime importance for enhancing the quality of education (Kothari Commission, 1964-66). Similarly, several researchers have consensually pinpointed the crucial role of teachers in students' success (e.g., Darling-Hammond, 2000; Day et al., 2007; den Brok, Brekelmans, \& Wubbels, 2004; Rivkin, Hanushek, \& Kain, 2005). More specifically, the theoretical pendulum has swung back and forth concerning the different roles of language teachers (Pishghadam, Zabihi, \& Norouz Kermanshahi, 2012).

During the pre-modern era of ELT; best characterized by the dominance of the Classical Method as the best method of teaching the language; language teachers were regarded as the sole authorities in the class and normally relied on their own intuition for teaching the language. Moreover, the Classical Method (Later known as the Grammar Translation Method) aimed at teaching classical languages like Latin and Greek via translating literary texts and was centered on rote learning of vocabulary and grammar rules. By and large, the practitioners of this method tended to ignore listening and speaking skills, giving much precedence to vocabulary memorization, grammar, and reading and writing.

In the modern era, the language teaching practitioners were expected to be as native-like as possible. Further, while English-speaking teachers were regarded as the best teachers, monolingual instruction was deemed as the most palatable type of language teaching. Besides, these teachers tended to take on the role of a technician and a classroom consumer; that is, they transmitted the expert knowledge to learners, while learners did not have the right to change or modify the information content (Kincheloe, 1993).

The postmodern era of ELT came into being along with the notions of subjectivism, constructivism, relativism and localism (Kuhn, 1962); postmodernists such as Kumaravadivelu (1994), Pennycook (1989), Long (1989), Prabhu (1990), Richards (1990, 2003) and Stern (1991) rejected the modernist ideas and practices and, on the contrary, they empowered language teachers to reflect on their own practices in teaching. Later in that period, language teachers were enfranchised to put into question the existing socio-political, historical and ideological forces for the purpose of enabling learners to gain the required knowledge and skills to be able to function as critical agents in society (Auerbach, 1995; Kumaravadivelu, 1999; Pennycook, 1999).

Thanks to the emergence of the theory of Applied ELT (Pishghadam, 2011); which considered ELT as an independent and scientific field ready to contribute to and be applied to other disciplines, language teachers were recommended to go beyond reflective, critical, and participatory language teaching; rather, from then on, they were considered to be educational language teachers in the sense that they were required to become interdisciplinary instructors who have not only a thorough knowledge of the ELT field, but also a fair knowledge of other fields as well (Pishghadam, Zabihi, \& Norouz Kermanshahi, 2012). Be that as it may, ELT teachers are the key agents of enhancing several skills that are of prime importance in learners' lives. This is quite in line with the premises of humanistic education which backs the idea that education should empower people to lead a meaningful and purposeful life by boosting their intellectual and emotional abilities as well as their other types of relationships, attitudes, values and thinking styles.

As Matheson and Grosvenor (1999) have pointed out, there are some core life skills that should be worked on in schools alongside other academic subjects. In this line, life skills are characterized as "the abilities for adaptive and positive behavior that enable individuals to deal effectively with the demands and challenges of everyday life" (WHO, 1999). The core life skills proposed by the World Health Organization (WHO) encompass 
A mixed methods approach to analyzing L2 teachers' attitudes towards critical thinking instruction

problem solving, decision making, interpersonal relationship skills, creative thinking, coping with emotions, coping with stress, effective communication, self-awareness, critical thinking, and empathy and understanding. Accordingly, several researchers and scholars (e.g., Brooks, 2001; Francis, 2007; Goody, 2001; Larson \& Cook, 1985; Matthews, 2006; Noddings, 2003; Radja, Hoffmann, \& Bakhshi, 2008; Spence, 2003; Walker, 1999) have highlighted the fact that these life skills should be pre-arranged to be improved in educational contexts. In much the same way, many educational philosophers such as Freire (1998), Dewey (1897), Krishnamurti (1981) and Walters (1997) have highlighted the significance of life skills in any education system.

In recent years, Pishghadam (2011) has brought us up to date with an informed discussion of the theory of Applied ELT by which he means that ELT, by virtue of its interdisciplinary nature and scientific acceptability, has now declared its independence from the confines of linguistics and has thus gained the capability to be applied and contribute to other domains of knowledge such as psychology and sociology. Besides, thanks to the several distinctive features that ELT classes provide learners and teacher with, it can set the scene for the promotion of several life skills. Moreover, the idea was extended by the introduction of life syllabus based on which language teachers are recommended to give more precedence to life skills in ELT classes (Pishghadam \& Zabihi, 2012).

Under this account, ELT professionals are henceforth liable for improving learners' whole-person growth, including both their intellectual development as well as other issues which are of prime importance in their lives. One of these issues which had been cited in the literature as an essential skill in people's lives is 'critical thinking' (Hare, 1999). While the need to enhance critical thinking abilities in language learners may appear self-evident, the potential and actual incorporation of this skill in the ELT curriculum remains unclear. This study aims at exploring language teachers' beliefs as to the importance of including critical thinking in the ELT curriculum.

\section{Background and Purpose}

No doubt that to improve people's life quality many factors should be taken into account. These factors include, inter alia, social relations, safety, mental health, happiness, human rights, freedom, marriage success, creative and critical thinking abilities, emotional competencies and job satisfaction. Besides, it is widely acknowledged that the enhancement of these factors should be seriously taken into account in the context of education. Accordingly, several antecedents, or forerunners, of life skills education, i.e. (i) Humanistic education, (ii) philosophy of Education for Life (EFL), (iii) World Health Organization (WHO), (iv) the Targeting Life Skills (TLS) Model, (v) the UNESCO Institute for Education, (vi) Life Skills-Based Education (LSBE) and (vii) the Human Development Paradigm (HDP), have been proposed by Pishghadam, Zabihi, and Ghadiri (2012) in order to throw some light on the importance of improving life skills in education.

As one of the forerunners of life skills education, the World Health Organization (WHO) has initially been established with the aim of enhancing the mental and social well-being of children. In this connection, life skills are defined as "the abilities for adaptive and positive behavior that enable individuals to deal effectively with the demands and challenges of everyday life" (WHO, 1999). In much the same way, the United Nations International Children's Emergency Fund (UNICEF) has characterized life skills as "a behavior change or behavior development approach designed to address a balance of three areas: knowledge, attitude and skills" (www.unicef.org). In this line, the Delors Report (1996), whose mission is to give education the role of providing humanity with the capacity to control its own development, was put forward with four educational pillars, namely learning to be, learning to know, learning to live together, and learning to do. These advances have led to the preparation of a proposal entitled Education for Human Development which is based on the idea that any education has the responsibility to generate learning as well as to help students develop their other potentials and capabilities. Accordingly, attempts have been made by some organizations such as UNESCO and the Ayrton Senna Institute to apply the four fundamental areas of learning proposed by Delors et al. (1996) with the aim of catering for and nourishing different life skills like their multiple competencies, abilities, innate 
Ketabi, S., Zabihi, R., \& Ghadiri, M.

potentials, as well as their emotions and attitudes.

Recently, through the introduction of the notion of Applied ELT, Pishghadam (2011) puts forward the same argument for the field of English Language Teaching (ELT). Applied linguistics was once considered to be synonymous with language teaching (Strevens, 1992). Over time, ELT was being studied as a subpart of applied linguistics, and is presently open to endorse ideas from many branches of applied linguistics such as sociolinguistics and psycholinguistics. These fields have inspired the professionals of ELT in improving their knowledge of the field. Nonetheless, as Schmitt (2002) has argued, these ideas which are in the form of prescriptions for enhancing the field of ELT might turn English language teachers into consumers of the findings of other disciplines.

Considering the fact that any discipline has two integral parts of theoretical and applied, Pishghadam (2011) is concerned with the fact that the applied part has not received well-deserved attention in the field of ELT. Further, he argues that language teachers should not be the consumers of the findings of other disciplines any longer; rather, they should henceforth more contributory and life-changing role. In other words, thanks to its interdisciplinary and scientific propriety, ELT has now gained the capability to be applied and contribute to other domains of knowledge. Moreover, granted that ELT classes enjoy several unique features, they can be the sites where many life skills may be prescheduled to be improved (Pishghadam \& Zabihi, 2012). These distinctive features include, among others, (a) discussing a large number of social, scientific, and political topics, (b) holding pair work and group work in class, (c) comparing two cultures, (d) getting acquainted with the words and grammar of another language, (e) speaking in another language in which one can show their own real self, (f) taking language learning very seriously, and (g) having a funny and friendly atmosphere for learning (Pishghadam, 2011).

Applied ELT was further expanded by Pishghadam and Zabihi (2012) whose purpose was to put forward Life Syllabus as a roadmap for the ELT community to consider the improvement of these life skills prior to language learning. In the light of this corollary, ELT classes can therefore be suitable places for a life skills training enterprise. Life skills training is thus a beneficial and value-addition practice, both in general education and in ELT, in the sense that it tries to make individuals ready for meeting the life's challenges and obstacles such as anxiety, stress, depression, burnout, alongside other educational needs.

In this connection, one of the essential life issues which has recurrently been cited in the literature to be an important skill in life skills education is critical thinking (Hare, 1999). Moreover, several researchers have acknowledged the key role played by critical thinking in individuals' academic success (e.g., Birjandi \& Bagherkazemi, 2010; Fahim, Bagherkazemi, \& Alemi, 2010; McCutcheon, Apperson, Hanson, \& Wynn, 1992; Yeh \& Wu, 1992). More specifically, in the field of ELT, several scholars and researchers have deemed critical pedagogy and critical language awareness to be significant notions in language teaching (Canagarajah, 1999; Norton \& Toohey, 2004; Pennycook, 1999, 2001; Ramanathan, 2002). Under this account, language tasks which demand that learners employ greater degrees of elaboration and criticality need more instruction in critical thinking; hence, critical thinking which is characterized by the ability of an individual to explore, criticize, or advocate a variety of ideas, to reason inductively and deductively, and to infer sound conclusions from ambiguous statements (Freeley \& Steinberg, 2000), should be the mainstay of L2 teaching classes.

As it was mentioned above, while there apparently seems to be a need to improve critical thinking in language learners, the potential and actual incorporation of this skill in the ELT curriculum remains unclear. What is of particular interest in that such a concern is not limited to any one country, but appears to affect systems of education all over the world (Stapleton, 2011). This study aims at exploring language teachers' beliefs as to the importance of including critical thinking in the ELT curriculum. Therefore, in this study we attempted to explore whether and to what extent EFL teachers believe that critical thinking should be incorporated into the ELT curriculum. The following research question was thus addressed in this study:

1. What are the attitudes of language teachers towards the inclusion of critical thinking in the ELT 
A mixed methods approach to analyzing L2 teachers' attitudes towards critical thinking instruction curriculum?

2. To what extent do language teachers believe that critical thinking should be incorporated into the ELT curriculum?

\section{Method}

In the present study, a triangulation of questionnaires and face-to-face interviews was used in order to enrich the validity of inferences that are to be made (Johnson, Onwuegbuzie, \& Turner, 2007).

\subsection{Participants}

\subsubsection{Questionnaire Participants}

A total of 106 Iranian EFL teachers at six Iranian universities, i.e. the University of Isfahan, Ferdowsi University of Mashhad, Khorasgan University, Arak University, Imam Reza University, and Abadan Institute of Technology (AIT) took part in this study. They ranged in age from 25 to 44 and were graduate-level university professors of English teaching, translation, linguistics and literature. The sample consisted of both male and female EFL teachers. The number of male and female teachers was 32 and 74, respectively. The detailed information on the participants is shown in Table 1.

\section{Table 1}

Distribution of questionnaire participants

\begin{tabular}{|c|c|c|c|c|c|c|c|}
\hline Sex & & Age & & Degree & \multicolumn{3}{|c|}{ Teaching Experience (year) } \\
\hline Male & 32 & Twenties & 69 & English Teaching & 43 & Less than two years & 33 \\
\hline \multirow[t]{6}{*}{ Female } & 74 & Thirties & 26 & English Literature & 35 & 2-4 years & 43 \\
\hline & & Forties & 7 & English Translation & 20 & $5-9$ years & 19 \\
\hline & & Fifties & 4 & English Linguistics & 8 & 10-14 years & 5 \\
\hline & & & & & & 15-19 years & 2 \\
\hline & & & & & & 20-24 years & 3 \\
\hline & & & & & & 25-30 years & 1 \\
\hline Total & 106 & & & & & & 106 \\
\hline
\end{tabular}

\subsubsection{Interview Participants}

Through purposive sampling, five EFL teachers were selected to be interviewed. In order to select the participants, four criteria were taken into consideration: (a) they all agreed to take part in this study voluntarily; (b) they should have filled out the questionnaire before; (c) they should also have completed their MA and PhD in English Language Education; and (d) they should have had experience of teaching the English language at universities for at least two semesters. The detailed information on the participants in the interview is shown in Table 2 .

Table 2

Characteristics of the interviewees

\begin{tabular}{cclllc}
\hline No & Age & Gender & \multicolumn{1}{c}{ Major } & Degree & Teaching Experience \\
\hline 1 & 27 & Female & TEFL & MA & 9 \\
2 & 26 & Female & TEFL & MA & 3 \\
3 & 24 & Male & TEFL & PhD Candidate & 2 \\
4 & 31 & Female & TEFL & MA & 12 \\
5 & 29 & Male & Linguistics & PhD Candidate & 8 \\
\hline
\end{tabular}

\subsection{Data collection and analysis}

The survey instrument encompassed an eight-item questionnaire on a Liker scale of 5 points which explored 
Ketabi, S., Zabihi, R., \& Ghadiri, M.

(1) the language teachers' attitudes towards the meaning of critical thinking, (2) the status of critical thinking in their teaching career and content area, and (3) the perceived need for training to improve techniques in teaching a variety of critical thinking abilities. The questionnaire also included questions about the background information of the participants. While the main instrument in this paper was the questionnaire, face-to-face interviews were also conducted with five participants who could meet the aforementioned four conditions in order to attain a more in-depth understanding of teachers' conceptions about the necessity of including critical thinking as a life skill in the ELT curriculum.

Face-to-face interview was carried out in Persian (and then translated into English) in August 2012 and lasted for about 10-15 minutes. The interviewer attentively conducted the interviews and watchfully analyzed the data. Prior to the interview, the interviewees were told that their participation would be voluntarily, that they could stop the interview if the questions were improper and that the researchers would take notice not to disclose the data, except for the aims of the study. The interviewer did her best to make a responsive relationship with interviewees so that they could provide unreserved explanations concerning their beliefs and teaching practices. Table 3 contains the interview questions. Data were subsequently transcribed, modified, analyzed and translated into English. Authors have made an attempt to circumspectly transcribe the data so that it could precisely reflect the ideas and beliefs of the teachers, although a few very minor amendments have been made accordingly.

\section{Table 3}

Interview questions

\begin{tabular}{cl}
\hline No. & \multicolumn{1}{c}{ Interview questions } \\
\hline 1 & What does the term "critical thinking" mean to you? \\
2 & Do you think Iranian EFL learners in general are good critical thinkers? (Likert) \\
3 & If so, can you give an example that supports why you think they are good at critical thinking? \\
4 & If not, can you give an example that supports why you think they are not good at critical thinking? \\
5 & Do you encourage critical thinking as a language teacher in your classroom? \\
6 & If so, how do you encourage it? \\
7 & If not, why do you not encourage it? \\
8 & Do you think critical thinking should play a stronger role in the ELT curriculum? \\
9 & In what way do you think critical thinking could be given a higher priority in the ELT curriculum? \\
10 & What impediments are there to teaching critical thinking in ELT classes? \\
11 & Do English language exams include critical thinking questions? \\
\hline
\end{tabular}

\section{Results and Discussion}

\subsection{Questionnaire}

Table 4 presents the means and standard deviations for the eight items in the questionnaire. The reliability of the scale estimated by Cronbach alpha was 0.68 . Three items generated the strongest conceptions with language teachers expressing a firm agreement that language teachers need more training about how to teach critical thinking skills $(\mathrm{M}=3.86)$, that teaching critical thinking skills is an important part of their job as language teachers $(M=3.71)$, and that it is necessary to incorporate critical thinking into the ELT curriculum $(M=3.65)$. The other similar items produced relatively forceful responses, generally agreeing with the idea that they have a clear understanding of what critical thinking actually entails $(\mathrm{M}=3.11)$, that they build critical thinking explanations and exercises into most of their English lessons $(\mathrm{M}=3.12)$, and that critical thinking is especially important in English language teaching classes $(M=3.16)$.

On the other hand, the participants displayed a weak collective agreement that it is the primary job of the teacher to teach critical thinking in the classroom $(\mathrm{M}=2.90)$ and that Iranian EFL learners are generally good at critical thinking $(M=2.19)$. Taken as a whole, it can be said that the teachers felt they had a clear idea of what critical thinking is; that it is essential, and that it can be taught by the language teacher, perhaps because they believed that Iranian EFL learners were weak in this area. Accordingly, they also had a strong conception that 
A mixed methods approach to analyzing L2 teachers' attitudes towards critical thinking instruction there is a need for training teachers on how to teach critical thinking in ELT classes.

\title{
Table 4
}

Mean scores and standard deviations of the questionnaire items

\begin{tabular}{|c|c|c|}
\hline No. & Item & Mean \\
\hline 1 & Language teachers need more training about how to teach critical thinking skills. & 3.86 \\
\hline 2 & Teaching critical thinking skills is an important part of my job as a language teacher. & 3.71 \\
\hline 3 & It is necessary to incorporate critical thinking into the ELT curriculum. & 3.65 \\
\hline 4 & Critical thinking is especially important in English language teaching classes. & 3.16 \\
\hline 5 & I build critical thinking explanations and exercises into most of my English lessons. & 3.12 \\
\hline 6 & I have a clear understanding of what critical thinking actually entails. & 3.11 \\
\hline 7 & It is the primary job of the teacher to teach critical thinking in the classroom. & 2.90 \\
\hline 8 & Iranian EFL learners are generally good at critical thinking. & 2.19 \\
\hline
\end{tabular}

\subsection{Interview}

The second set of data we turn to are audio-recorded conversations with five EFL teachers. Data from these interviews, carried out with a purposive sampling procedure, provided us with further insights into the language teachers' attitudes towards the inclusion of critical thinking abilities in the form of life syllabus in ELT classes. In all, the interviewees indicated that critical thinking should form part of the ELT curriculum, expressing the belief that there is a need for extensive training in how to teach critical thinking among Iranian EFL teachers. Nonetheless, it seems too strong a statement to say that language teachers had specific definitions of what critical thinking actually entails. On the contrary, they appeared to have quite general and vague conceptions of the term.

Strong responses to three of the questionnaire items i.e., agreement towards ideas such as "it is essential to teach critical thinking", "it is the job of the language teacher to teach critical thinking" and "language teachers need more training about how to teach critical thinking skills" received enough support when the interview transcripts were analyzed. These findings espouse the idea that language teachers in Iran actually believe in instilling critical thinking as a pedagogical goal in English language classes. This finding is further supported by the general agreement among the interviewees that Iranian EFL teachers are lacking in critical thinking abilities. Therefore, the interviewees' strongest views can be voiced succinctly as follows:

\begin{abstract}
In my opinion, it is mandatory that critical thinking be taught and be incorporated into the whole ELT syllabus; this is legible when we find out that Iranian learners, the same as Iranian English teaching textbooks at schools, institutes, and even universities, are lacking the potentiality to raise the critical awareness of language learners.
\end{abstract}

The various responses given to a question by the interviewees regarding the definition of critical thinking seem to further complicate matters. That is to say, the interviewees generally depicted a general and vague conception of critical thinking that only in restricted ways dovetailed with definitions found in the literature. To put the discussion on a more concrete footing, the majority of their responses could be broadly classified under either "critical thinking as a thinking skill" or "critical thinking as a disposition". Such conceptions on the part of language teachers point to the fact that critical thinking means different things to different people, yet no one could clearly stipulate the different subcomponents of the construct. None of the participants in the interview referred to the fact that critical thinking encompasses several sub-skills such as recognizing assumptions, drawing inferences, interpreting evidence, making deductions, and evaluating arguments.

Taken together, the comments provided by the interviewees, like the participants' responses to the questionnaire items, revealed that while most of the participants had clear conceptions of what critical thinking consists of, their views seemed to be rudimentary and in many cases incomplete and shallow. Nonetheless, while four of the interviewees acknowledged that there should be courses in which critical thinking is very much highlighted as a core academic skill, two of them made reservations as to the possibility of such an enterprise 
Ketabi, S., Zabihi, R., \& Ghadiri, M.

and referred to the lack of critical thinking abilities on the part of Iranian language teachers which could prevent them from taking a fresh outlook to language teaching. This finding lends enough support to the claim made by Pishghadam, Zabihi, and Norouz Kermanshahi's (2012) claim that ELT teachers should become "Educational Language Teachers" (p. 893) who are not only English teaching experts but also knowledgeable professionals in different other disciplines of knowledge such as psychology.

\section{Conclusions and Implications for Practice}

The study reported in this paper explored the conceptions of EFL teachers in Iran regarding the necessity of incorporating critical thinking abilities in the curriculum in the form of life syllabi. Despite the fact that the enhancement of life skills has for many years been advocated in the context of education (Francis, 2007; Goody, 2001; Larson \& Cook, 1985; Radja, Hoffmann, \& Bakhshi, 2008; Spence, 2003), it seems that, at least in the case of critical thinking, both English language teachers and language learners are lagging behind. Although the data from a sizeable sample of EFL teachers in Iran may provide only hints about the beliefs towards critical thinking, the findings of this study can be taken as indicators that 'how' and 'to what extent' it should be taught is both needed and desired. In the light of this corollary, given the firm support that the teaching of critical thinking has received from educational authorities, not to mention the support it received from the Iranian EFL teachers in the present study, it is startling that more illumination on how to implement this kind of instruction has not appeared to date.

Therefore, some implications from the results of this study can be summarized as follows. First, the results of this study may be a sort of consciousness-raising for the ELT professionals who should recognize the necessity of teaching critical thinking abilities explicitly in language classes and set the scene for the integration of critical thinking courses in to the whole ELT curriculum. Moreover, ELT practitioners should become familiar with different techniques and materials that can help facilitate the enhancement of learners' critical thinking abilities. Besides, by virtue of the interdisciplinary nature of ELT, it is suggested that there should be a close interaction between English teachers and psychologists to provide great opportunities for the promotion of criticality among language learners.

The good news coming out of this study is that recent innovations, movements, and paradigm shifts seem to have been put forward by Pishghadam and others (e.g., Pishghadam, 2011; Pishghadam \& Zabihi, 2012; Pishghadam, Zabihi, \& Norouz Kermanshahi, 2012; Pishghadam, Zabihi, \& Ghadiri, 2012) towards including several life skills in the English language teaching curriculum. Further research may examine teachers' understanding of, and attitudes towards, critical thinking instruction in other contexts in order to come up with a solid understanding of the status of this construct among L2 teachers. Other studies using a larger sample of language teachers may better delineate the nuances of difference in the conceptions of language teachers with different levels of teaching experience. A need is also felt that the professionals in the field of English language teaching realize the importance of explicit instruction in critical thinking in language classes and the inclusion of critical thinking abilities in the whole ELT curriculum.

\section{References}

Auerbach, E. R. (1995). The politics of the ESL classroom: Issues of power in pedagogical choices. In J. W. Tellefson (Ed.). Power and inequality in language education. Cambridge: Cambridge University Press.

Birjandi, P., \& Bagherkazemi, M. (2010). The relationship between Iranian EFL teachers' critical thinking ability and their professional success. English Language Teaching, 3(2), 135-145.

Brooks, R. (2001) Fostering motivation, hope, and resilience in children with learning disorders. Annals of Dyslexia, 51, 9-20. http://dx.doi.org/10.1007/s11881-001-0003-4

Canagarajah, A. S. (1999). Resisting linguistic imperialism in English teaching. Oxford: Oxford University.

Darling-Hammond, L. (2000). Teacher quality and student achievement: A review of state policy evidence. Educational Policy Analysis Archives, 8(1). Retrieved from http://epaa.asu.edu/epaa/v8n1 
A mixed methods approach to analyzing L2 teachers' attitudes towards critical thinking instruction

Day, C., Sammons, P., Stobart, G., Kington, A., \& Gu, Q. (2007). Teachers matter: Connecting lives, work and effectiveness. Maidenhead: OpenUniversity Press.

den Brock, P., Brekelmans, M., \& Wubbels, T. (2004). Interpersonal teacher behavior and student outcomes.

School Effectiveness and School Improvement, 15, 407-442.

http://dx.doi.org/10.1080/09243450512331383262

Dewey, J. (1897). My pedagogic creed. The School Journal, 54 (3), 77-80.

Fahim, M., Bagherkazemi, M., \& Alemi, M. (2010). The relationship between test takers' critical thinking ability and their performance on the reading section of TOEFL. Journal of Language Teaching and Research, 1(6), 830-837. http://dx.doi.org/10.4304/jltr.1.6.830-837

Francis, M. (2007). Life skills education. Retrieved from http://www.changingminds.org

Freeley, A. J., \& Steinberg, D. L. (2000). Argumentation and debate: Critical thinking for reasoned decision making (10th ed.). Wadsworth: Thomson Learning.

Freire, P. (1998). Pedagogy of freedom: Ethics, democracy, and civic courage. Lanham, Maryland: Rowman \& Littlefield Publishers, Inc.

Goody, J. (2001). Competencies and education: Contextual diversity. In D. S. Rychen \& L. H. Salganik (Eds.), Defining and selecting key competencies. Gottingen, Hogrefe and Huber Publications.

Hare, W. (1999). Critical thinking as an aim of education. In R. Marples (Ed.), The aims of education. London: Routledge.

Johnson, R. B., Onwuegbuzie, A. J., \& Turner, L. A. (2007). Toward a definition of mixed methods research. Journal of Mixed Methods Research, 1(2), 112-133. http://dx.doi.org/10.1177/1558689806298224

Kincheloe, J. L. (1993). Toward a critical politics of teacher thinking. Westport: Bergin \& Garvey.

Krishnamurti, J. (1981). Education and the significance of life. HarperCollins Publishers.

Kuhn, T. (1962). The structure of scientific revolutions. Chicago: University of Chicago Press.

Kumaravadivelu, B. (1994). The post-method condition: Emerging strategies for second/foreign language teaching. TESOL Quarterly, 28, 27-48. http://dx.doi.org/10.2307/3587197

Kumaravadivelu, B. (1999). Theorizing practice, practicing theory: Critical classroom observation. In H. Trappes-Lomax \& I. McGrath (Eds.). Theory in language teacher education (pp. 33-45). London: Prentice-Hall.

Larson, D. G., \& Cook, R. E. (1985). Life-skills training in education. Journal of Group Psychotherapy, Psychodrama, \& Sociometry, 38(1), 11-22.

Long, M. H. (1989). Process and product in ESL program evaluation. Paper presented at the $5^{\text {th }}$ Annual TESOL Summer Meeting, Toronto, Canada, July 21-32.

Matheson, D., \& Grosvenor, I. (Eds.) (1999). An Introduction to the study of education. London: David Fulton Publisher.

Matthews, B. (2006). Engaging education: Developing emotional literacy, equity, and co-education. McGraw-Hill Education: Open University Press.

McCutcheon, L. E., Apperson, J. M., Hanson, E., \& Wynn, V. (1992). Relationships among critical thinking skills, academic achievement, and misconceptions about psychology. Psychological Reports, 71, 635-639.

Noddings, N. (2003). Happiness and education. Cambridge: Cambridge University Press. http://dx.doi.org/10.1017/CBO9780511499920

Norton, B., \& Toohey, K. (2004). Critical pedagogies and language learning. Cambridge: Cambridge University Press.

Pennycook, A. (1989). The concept of method, interested knowledge, and the politics of language teaching. TESOL Quarterly, 23(4), 589-618. http://dx.doi.org/10.2307/3587534

Pennycook, A. (1999). Introduction: Critical approaches to TESOL. TESOL Quarterly, 33, 329-348. http://dx.doi.org/10.2307/3587668

Pishghadam, R. (2011). Introducing Applied ELT as a new approach in second/foreign language studies. Iranian EFL Journal, 7(2), 9-20.

Pishghadam, R., \& Zabihi, R. (2012). Life syllabus: A new research agenda in English language teaching. 
Ketabi, S., Zabihi, R., \& Ghadiri, M.

TESOL Arabia Perspectives, 19(1), 23-27.

Pishghadam, R., Zabihi, R., \& Ghadiri, M. (2012). Opening up a new pathway to the future of ELT: Design and validation of a life-responsive language teaching beliefs scale for L2 teachers. Proceedings of the $1^{\text {st }}$ Conference on Language Learning and Teaching: An Interdisciplinary Approach (LLT-IA), Ferdowsi University of Mashhad, Iran.

Pishghadam, R., Zabihi, R., \& Norouz Kermanshahi, P. (2012). Educational language teaching: A new movement beyond reflective/critical teaching. Life Science Journal, 9(1), 892-899.

Prabhu, N. S. (1990). There is no best method-why? TESOL Quarterly, 24, 161-176. http://dx.doi.org/10.2307/3586897

Radja, K., Hoffmann, A. M., \& Bakhshi, P. (2008). Education and capabilities approach: Life skills education as a bridge to human capabilities. Retrieved from http://ethique.perso.neuf.fr/Hoffmann_Radja_Bakhshi.pdf

Ramanathan, V. (2002). The politics of TESOL education. New York: Routledge Falmer/Taylor \& Francis.

Richards, J. C. (1990). The language teaching matrix. Cambridge: Cambridge University Press. http://dx.doi.org/10.1017/CBO9780511667152

Richards, J. C. (2003). Beyond methods. In C. Candlin \& N. Mercer (Eds.), English language teaching in its social context (pp. 167-179). London and New York: Routledge.

Rivkin, S. G., Hanushek, E. A., \& Kain, J. F. (2005). Variable definitions, data, and programs for teachers, students, and academic achievement. Econometrica Supplementary Material, 73(2). Retrieved from http://www.econometricsociety.org/ecta/supmat/4139data.pdf

Schmitt, N. (2002). An introduction to applied linguistics, London: Arnold.

Spence, S. H. (2003). Social skills training with children and young people: Theory, evidence and practice. Child and Adolescent Mental Health. 8(2), 84-96. http://dx.doi.org/10.1111/1475-3588.00051

Stapleton, P. (2011). A survey of attitudes towards critical thinking among Hong Kong secondary school teachers: Implications for policy change. Thinking Skills and Creativity, 6, 14-23. http://dx.doi.org/10.1016/j.tsc.2010.11.002

Stern, H. H. (1991). Fundamental concepts of language teaching. Oxford: Oxford University Press.

Strevens, P. (1992). Applied linguistics: An overview. In W. Grabe \& R. B. Kaplan (Eds.), Introduction to applied linguistics (pp. 13-31). Addison-Wesley Publishing Company.

Walker, J. C. (1999). Self-determination as an educational aim. In R. Marples (Ed.), The aims of education. London: Routledge.

Walters, J. D. (1997). Education for life: Preparing children to meet the challenges. Crystal Clarity Publishers.

WHO. (1999). Partners in life skills education: Conclusions from a United Nations inter-agency meeting. Geneva: Department of Mental Health, Social Change and Mental Health Cluster, WHO.

Yeh, Y., \& Wu, J. (1992). The relationship between critical thinking and academic achievement among elementary and secondary school students. Journal of Education and Psychology, 15, 79-100. 